\title{
A Message from the President of Geological Society of India
}

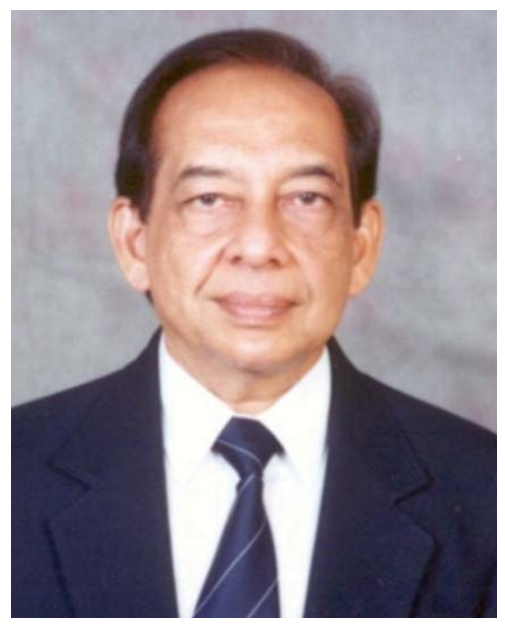

In the $21^{\text {st }}$ Century, the Geological Sciences are attaining an increasingly important position globally. As the very sustenance of Planet Earth depends on how well we understand its functioning.

The International Union of Geological Sciences (IUGS) is one of the largest and most active non-governmental scientific organizations in the world. Founded in 1961, IUGS is a member of the International Council of Science. IUGS promotes and encourages the study of geological problems, especially those of world-wide significance, and supports and facilitates international and interdisciplinary cooperation in the earth sciences. At present IUGS gives special consideration to: (i) initiatives related to the identification and assessment of energy and mineral resources; (ii) global change; (iii) geological hazards; and (iv) environmental geology.

Episodes is the official quarterly journal of the International Union of Geological Sciences (IUGS). It covers developments of regional and global importance in the earth sciences and is distributed worldwide in March, June, September, and December. Episodes form one of the most important media to address current global problems such as climate change, depleting fresh water resources, environmental pollution, geological hazards and management of waste, geological education to prepare population to anticipate and cope up with changing environments and global climate change. Episodes is listed or abstracted in Chemical Abstracts, Coal Abstracts, Energy Research Abstracts, Excerpta Medica, Geological Abstracts, Geoarchives, Georef, and Ulrich's International Periodicals Directory. An annual index is published in the last issue of each volume.

From 1997, initially the former Chinese Ministry of Geology and Mineral Resources (MGMR) and then the Ministry of Land and Resources (MLR) has been providing editorial and production support. For the past twelve years the Chinese team has done an excellent job in bringing out high quality papers.

During 2008 at the $33^{\text {rd }}$ International Geological Congress at Oslo, the IUGS extended an invitation to the Geological Society of India, Bangalore, to provide editorial and production support to publish Episodes from 2009. The Geological Society of India has accepted the invitation and entered a Memorandum of Understanding (MOU) with IUGS for four years (2009-2012) to publish Episodes. Following the MOU we have identified Prof. M. Jayananda, a reputed scientist with wide international contacts, as Editor.

I wish the Journal all the success.

HARSH GuPTA

President

Geological Society of India 